\title{
Clinical, Electrophysiological and Molecular Features in Hereditary Neuropathy with Liability to Pressure Palsies
}

\section{Características Clínicas, Neurofisiológicas e Moleculares na Neuropatia Hereditária com Sensibilidade às Paralisias de Pressão}

(D) Joana Afonso Ribeiro 1, Luciano Almendra ${ }^{2}$, Anabela Matos ${ }^{2}$, (D) Argemiro Geraldo ${ }^{2}$, Luís Negrão ${ }^{2, *}$

1-Centro de Desenvolvimento da Criança, Hospital Pediátrico de Coimbra; Centro Hospitalar e Universitário de Coimbra, Coimbra, Portugal

2-Unidade de Doenças Neuromusculares, Serviço de Neurologia, Hospitais da Universidade de Coimbra / Centro Hospitalar e Universitário de Coimbra, Coimbra, Portugal

DOI: https://doi.org/10.46531/sinapse/AO/200055/2020

\section{Abstract}

Introduction: Hereditary neuropathy with liability to pressure palsies (HNPP) is an autosomal-dominant inherited peripheral neuropathy caused by deletions of the PMP22 gene (PMP22). It is classically characterized by episodes of repeated focal pressure neuropathies at common entrapment sites. Atypical forms are recognized and may occur in up to $56 \%$ of HNPP patients. The electrophysiological characteristics and the genetic studies are paramount for its diagnosis. We aim to describe clinical, electrophysiological and genetic features of a cohort of patients diagnosed with HNPP at a tertiary hospital.

Methods: Retrospective study of patients with a confirmed diagnosis of HNPP, using descriptive statistics for their characterization.

Results: Seventeen patients from 15 different families were included. Nine were males, and the overall mean age was 42.6 years-old. Age at first symptoms ranged from 3 to 46 years-old, with mean time until diagnosis of 9.3 years. Nine patients (53\%) presented recurrent painless mononeuropathies or isolated focal compressive neuropathies, and eight patients (47\%) had atypical presentation phenotypes, such as "Charcot-Marie-Tooth-like (CMT-like) and sensory neuropathy. Intra-familial clinical heterogeneity was observed. All patients showed nerve conduction slowing at common entrapment sites (median, ulnar and peroneal nerves), and signs of a more generalized peripheral nerve involvement were present in more than half of the patients. Fifteen patients carried the PMP22 gene deletion, and point mutations were present in two.

Conclusion: Our cohort presents similar clinical characteristics to the literature description, with a significant proportion of patients with atypical presentations. The absence of clinical-electrophysiological correlation emphasise the importance of nerve conduction and genetic studies for the definite diagnosis of the disease.

\section{Resumo}

Introdução: A neuropatia hereditária com sensibilidade às paralisias de pressão (HNPP) é uma neuropatia periférica de hereditariedade autossómica dominante, causada por alterações genéticas no gene PMP22. Na sua forma clássica, caracteriza-se por episódios de neuropatias focais de repetição em locais comuns de compressão. Têm sido reconhecidas formas atípicas de doença, que podem ocorrer em até $56 \%$ dos
Informações/Informations: Artigo Original, publicado em Sinapse, Volume 20, Número

4, outubro-dezembro 2020. Versão eletrónica em www. sinapse.pt

Original Article, published in Sinapse, Volume 20, Number 4, October-december 2020.

Electronic version in www.

sinapse.pt

(C) Autor (es) (ou seu (s) empregador (es)) e Sinapse 2020. Reutilização permitida de acordo com CC BY-

NC. Nenhuma reutilização comercial.

(C) Author(s) (or their employer(s)) and Sinapse 2020. Re-use permitted under CC BY-

NC. No commercial re-use.

Keywords:

Hereditary Sensory and Motor Neuropathy/diagnosis;

Hereditary Sensory and Motor Neuropathy/physiopathology; Neural Conduction.

Palavras-chave:

Condução Nervosa;

Neuropatia Hereditária Motora e Sensorial/diagnóstico;

Neuropatia Hereditária Motora

e Sensorial/fisiopatologia.

\footnotetext{
*Autor Correspondente / Corresponding Author:

Luís Negrão

Unidade de Doenças

Neuromusculares

Serviço de Neurologia

"Hospitais da Universidade de

Coimbra Centro Hospitalar e

Universitário de Coimbra

Praceta Mota Pinto

3000-075 Coimbra, Portugal

luisnegraoster@gmail.com
}

Recebido / Received: 2020-09-27 Aceite / Accepted: 2020-11-05

Ahead of Print: 2020-12-21

Publicado / Published: 2021-01-18 
doentes com HNPP. Os achados neurofisiológicos e o estudo genético são essenciais para o seu diagnóstico. O objetivo deste trabalho é a descrição clínica, neurofisiológica e genética de uma coorte de doentes com HNPP acompanhados num hospital terciário.

Metodologia: Estudo retrospetivo de doentes com diagnóstico de HNPP, utilizando estatística descritiva para caracterização da amostra.

Resultados: Foram incluídos dezassete doentes pertencentes a quinze famílias, sendo nove do sexo masculino, com idade média de 42,6 anos. A idade de início da sintomatologia foi entre os 3 e os 46 anos, com um tempo médio até ao diagnóstico de 9,3 anos. Nove doentes (53\%) apresentaram-se com a forma típica da doença mononeuropatias indolores recorrentes ou neuropatias em locais de compressão, e oito doentes (47\%) apresentaram formas atípicas, como Charcot-Marie-Tooth-like (CMT-like) e neuropatias sensitivas. Observou-se variabilidade intra-familiar. No estudo neurofisiológico, todos os doentes apresentaram redução das velocidades de condução nervosa em locais comuns de compressão (nervos mediano, cubital e peroneal) e, em mais de metade, o envolvimento era mais generalizado. Quinze doentes apresentavam deleção no gene PMP22, e mutações pontuais foram descritas em dois doentes.

Conclusão: $O$ nosso grupo de doentes apresenta características semelhantes às descritas na literatura, com uma proporção significativa de doentes com apresentações clínicas atípicas. A ausência de correlação clinico-electrofisiológica salienta a importância dos estudos de condução nervosa e da genética para o diagnóstico definitivo da doença.

\section{Introduction}

Hereditary neuropathy with liability to pressure palsies (HNPP) is an autosomal-dominant inherited peripheral neuropathy, classically characterized by episodes of repeated focal pressure neuropathies at common entrapment sites. Atypical presentations may occur in up to $56 \%$ of patients. These phenotypes include Charcot-Marie-Tooth-like (CMT-like) polyneuropathy, chronic sensory polyneuropathy, progressive mononeuropathy, recurrent positional short-term sensory symptoms and presenting symptoms mimicking a Guillain-Barré syndrome. ${ }^{1-5}$ Therefore, in the diagnostic evaluation of HNPP, neurophysiological and genetic testing are essential. ${ }^{1-3}$

Electrophysiologically, the most common findings are abnormal sensory responses (absent or with low amplitude with prolonged latency), prolonged distal motor latencies with normal or slightly diminished conduction velocities (CV), and CV slowing, in the range of demyelination $(<39 \mathrm{~m} / \mathrm{s})$, at normal sites of entrapment. These changes are also observed in patients with atypical presentations. ${ }^{1,6-7}$ Albeit the absence of consensus for the neurophysiological changes in HNPP patients, guidelines for its diagnosis have been proposed (Table 1). ${ }^{8} \mathrm{~A}$ recent study defined
Table 1. Guidelines to the neurophysiologic diagnosis of HNPP

Diffuse electrophysiological abnormalities (all mutation carriers)

Bilateral increase in DML of the median nerve associated with bilateral reduced median sensory nerve conduction velocity at the palm-wrist segment and at least delayed DML or reduced MNCV in one of the peroneal nerves

MNCV of the ulnar nerve at the elbow segment is frequently reduced

MNCV in the lower limbs may be moderately reduced

Sensory nerve action potentials amplitudes may be reduced, mostly in the upper limbs

Based on Dubourgh $\mathrm{O}$, et al. Guidelines for the diagnosis of hereditary neuropathy with liability to pressure palsies.

DML - distal motor latency; MNCV - motor nerve conduction velocity.

that HNPP should be suspected in patients with an electrophysiological study showing a demyelinating neuropathy associated to carpal tunnel syndrome, plus another motor nerve conduction abnormality (diminished CV of the ulnar nerve at the elbow, prolonged distal motor latency of the ulnar nerve, diminished $\mathrm{CV}$ of the peroneal nerve at the fibular head) and a sensory nerve abnormality in a nerve not prone to compression (sural or radial nerves).'

Genetically, the most common mutation is a deletion on chromosome $17 \mathrm{p} / 2$ bearing the peripheral myelin protein 22 (PMP22) gene. Less often, the disease 
is caused by point mutations in the same gene. ${ }^{1,9}$ The most relevant genotype-phenotype correlation occurs in patients with a frameshift variant (p.Arg95GInfs I 28) - although usually presenting a typical HNPP phenotype, are more likely to have clinically evident motor or sensory neuropathy mimicking CMT-I. ${ }^{10}$ The estimated prevalence of the deletion causing HNPP in a Northern England population is estimated in 7.3/100 000 inhabitants, lower than CMT-IA, although both genetic changes are related to a reciprocal recombination event. " It is possible that HNPP is underdiagnosed, mainly due to the insidious nature and possible variable penetrance of the disease. ${ }^{1,3,11}$

Histopathological findings include focal sausageshaped thickening of the myelin sheath, called "tomacuIa", which is considered the hallmark of the disease. ${ }^{1-5,9}$

In this study we aim to describe clinical, electrophysiological and genetic features of seventeen patients with HNPP, observed in an adult Neuromuscular Disease Reference Unit.

\section{Material and Methods}

We retrospectively identified patients with a molecular confirmed diagnosis of HNPP, who attended the Neuromuscular Disease Unit of a tertiary referral Neuromuscular Disease Unit in central Portugal.

Clinical, neurophysiological, laboratory and genetic data were collected from medical records.

Nerve conduction studies (NCS) comprised motor and sensory evaluation in all patients. Motor NCS included ulnar and median nerves in the upper limbs and peroneal nerve in the lower limbs - the responses were recorded from abductor digiti minimi, abductor pollicis brevis, and extensor digitorum brevis muscles, respectively. Motor nerve $\mathrm{CV}$ was calculated in the above-below elbow and below elbow-wrist segments for the ulnar nerve; elbow-wrist segment for the median nerve; and popliteal fossa to fibular head and fibular head to ankle segments for peroneal nerve. Sensory nerve responses were recorded with the antidromic method. The ulnar and median sensory responses were recorded with ring electrodes placed in the index and fifth fingers, respectively, at a fixed distance of $14 \mathrm{~cm}$ from the cathode and sural nerve response was recorded with a bar electrode located behind the lateral malleolus at a distance of $12 \mathrm{~cm}$ from the cathode. If needed, these measures were adapted proportionally to patients' height.

The latencies of the compound motor action potential (CMAP) and sensory nerve action potential (SNAP) were measured from the shock artifact to the initial negative deflection or to the top of the initial positive deflection of the SNAP when it presented a triphasic form. Amplitude of the CMAP and SNAPs were measured from baseline to the top of the negative deflection. The results were considered abnormal when above two standard deviations from the mean normative value according to data of the Electromyography Laboratory. Partial motor nerve conduction block was defined by a reduction in $30 \%$ or more of the proximal CMAP amplitude and area compared to the distal CMAP. ${ }^{12}$

\section{Results}

We included 17 patients, nine males and eight females, with current mean age of 42.6 years-old (ranging from 21 to 70 years old). Their demographic and clinical characterization is showed in Table 2. Age of first clinical symptoms ranged from 3 to 46 years-old (median age of 21.5 years), with a mean time from first symptom to molecular diagnosis of HNPP of 9.3 years. None of the patients had personal history of diabetes mellitus or other medical comorbidities that could contribute to a peripheral neuropathy. The 17 patients belonged to 15 unrelated families, and two patients had a positive family history of a similar disease, although the affected relatives were not available for observation. In these familial cases, there were traits of autosomal-dominant transmission of a peripheral nervous system disorder, although clinical features were not the same between family members.

\section{I Clinical features}

We classified patients in two phenotypical presentations: typical (recurrent and painless mononeuropathies), and atypical.

Nine patients presented with recurrent painless mononeuropathies $(n=7)$ or isolated carpal tunnel syndrome $(n=2)$, considered the typical presentation of the disease. The reported age of first symptoms ranged from 12 to 35 years old (mean 18. I; median 16.0, standard deviation 7.9), with a male:female ratio of $6: 3$.

Eight patients had atypical presentations. First symptoms were reported from 3 to 46 years old 
(mean age 30.3; median 32.0; standard deviation 13.73), with a male:female ratio of 3:5.

A common symptom in a majority of patients was transient sensory changes following superficial compression, like carrying bags or leg crossing. Patients' current neurological manifestations are summarized in Table 2.

Table 2. Demographic and clinical characteristics of patients with HNPP

\begin{tabular}{|c|c|}
\hline \multicolumn{2}{|l|}{ Demographics } \\
\hline Gender proportion (Male:Female) & 9:8 \\
\hline Age at symptom-onset & 25.0 years $(12.8 ; 3-46)$ \\
\hline Current age/age at examination & 42.6 years $(14.5 ; 21-70)$ \\
\hline \multicolumn{2}{|l|}{ Clinical presentation } \\
\hline $\begin{array}{l}\text { Typical presentation } \\
\text { (recurrent neuropathies) }\end{array}$ & 9 (53\%) \\
\hline Peroneal neuropathy & 4 \\
\hline Ulnar neuropathy & 2 \\
\hline $\begin{array}{l}\text { Isolated bilateral carpal tunnel } \\
\text { syndrome }\end{array}$ & 2 \\
\hline Brachial plexopathy & 1 \\
\hline Atypical presentation & $8(47 \%)$ \\
\hline CMT-like & 4 \\
\hline Sensory neuropathy & 3 \\
\hline Guillain-Barré-like & 1 \\
\hline \multicolumn{2}{|l|}{ Current clinical features } \\
\hline \multicolumn{2}{|l|}{ Strength } \\
\hline Normal strength & $9(52.9 \%)$ \\
\hline LL weakness & $4(23.5 \%)$ \\
\hline UL and LL weakness & $4(23.5 \%)$ \\
\hline \multicolumn{2}{|l|}{ Sensation } \\
\hline Impaired vibration & $8(47.1 \%)$ \\
\hline Hyposthesia & $10(58.8 \%)$ \\
\hline Pes cavus & $5(29.4 \%)$ \\
\hline
\end{tabular}

Values represent absolute numbers (\%) and means (standard deviation; minimum-maximum)

LL - lower limbs; UL - upper limbs.

\section{a. Typical presentation ( $n=9$ patients)}

Four patients were observed at the time of first symptoms - three patients with a peroneal neuropathy and one patient with sensory changes in the upper limbs after cervical mobilization. One patient with right peroneal neuropathy reported a previous right foot drop in adolescence. One other patient reported transient upper right limb weakness, and presented at the neuromuscular unit with a right ulnar neuropathy at the elbow. The other patient presented a recurrent bilateral ulnar neuropathy, with spontaneous clinical remission. Two patients presented an isolated symptomatic bilateral carpal tunnel syndrome, but showed evidence of lower limb involvement in nerve conduction studies, which was clinically asymptomatic but allowed diagnosis of HNPP.

In this group, two unrelated female patients, now aged 49 and 35 years old (which presented with bilateral carpal tunnel syndrome and a peroneal neuropathy, respectively) came to develop clinical signs of chronic neuropathy, demonstrated by distal motor and sensory changes (predominant in lower limbs) and pes cavus. One other male patient, currently aged 56 years old, with an HNPP form of presentation with a transient peroneal neuropathy, ultimately developed a bilateral carpal tunnel syndrome.

\section{b. Atypical presentation ( $n=8$ patients)}

Four patients exhibited a CMT-like presentation - one female presented a severe chronic generalized neuropathy, starting in childhood (the youngest of our cohort); one male presented a mild chronic neuropathy predominantly affecting lower limbs since early adulthood; and two related patients, one male and one female, presented, respectively, a moderate neuropathy since adolescence and a mild neuropathy starting in adulthood.

Three female patients presented a chronic sensory neuropathy - one of these patients was under investigation for a neuropathy, and was diagnosed after her grand-daughter presented a typical HNPP phenotype.

Finally, one patient had an acute presentation mimicking a Guillain-Barré syndrome, and was also diagnosed with optic neuropathy and non-specific white matter brain lesions. Since his first clinical symptoms he had relapses consistent with a polyneuropathy.

\subsection{Electrophysiological features (Table 3)}

The electrophysiological features included generalized changes in motor and/or sensory nerve conduction studies, including diffuse sensory nerve con- 
Table 3. Motor and sensory nerve conduction studies.

\begin{tabular}{|c|c|c|c|c|c|}
\hline & n (\%) & Ref. values & & n (\%) & Ref. values \\
\hline \multicolumn{3}{|l|}{ Ulnar nerve } & \multicolumn{3}{|l|}{ Peroneal nerve } \\
\hline Prolonged DML & $6 / 17$ (35.6\%) & $<3.5 \mathrm{~ms}$ & Prolonged DML & $7 / 15$ (46.7\%) & $<6 \mathrm{~ms}$ \\
\hline MNCV forearm & $1 / 17$ (5.9\%) & $\geq 50 \mathrm{~m} / \mathrm{s}$ & MNCV leg & 5/15 (33.3\%) & $\geq 40 \mathrm{~m} / \mathrm{s}$ \\
\hline MNCV elbow & $12 / 16(75.0 \%)$ & & MNCV knee & $8 / 13$ (61.5\%) & \\
\hline Reduced distal CMAP & 2/16 (12.5\%) & $\geq 5 \mathrm{mV}$ & Diminished distal CMAP & 5/15 (33.3\%) & $\geq 2 \mathrm{mV}$ \\
\hline SNCV & $2 / 8(25.0 \%)$ & $\geq 45 \mathrm{~m} / \mathrm{s}$ & Absent distal CMAP & 4/15 (26.7\%) & \\
\hline Diminished SNAP & $2 / 8(25.0 \%)$ & $>12 \mu \mathrm{V}$ & & & \\
\hline Absent SNAP & $8 / 16$ (50.0\%) & & & & \\
\hline \multicolumn{3}{|l|}{ Median Nerve } & \multicolumn{3}{|l|}{ Sural Nerve } \\
\hline Prolonged DML & 16/17 (94.1\%) & $<4 \mathrm{~ms}$ & SCV & 4/5 (80.0\%) & $\geq 40 \mathrm{~m} / \mathrm{s}$ \\
\hline MNCV forearm & 2/17 (11.8\%) & $\geq 49 \mathrm{~m} / \mathrm{s}$ & Reduced SNAP & 3/16 (18.8\%) & $>6 \mu \mathrm{V}$ \\
\hline Reduced distal CMAP & 4/17 (23.5\%) & $\geq 4 \mathrm{mV}$ & Absent SNAP & $11 / 16(68.8 \%)$ & \\
\hline SNCV & 7/9 (77.8\%) & $\geq 45 \mathrm{~m} / \mathrm{s}$ & & & \\
\hline Diminished SNAP & 4/17 (23.5\%) & $>15 \mu \mathrm{V}$ & & & \\
\hline Absent SNAP & $8 / 17$ (47.1\%) & & & & \\
\hline
\end{tabular}

$\mathrm{n}$ - proportion of abnormal results for total number of explored nerves; DML - distal motor latency; MNCV - motor nerve conduction velocity; SNCV - sensory nerve conduction velocity; distal CMAP - distal compound muscle action potential;

SNAP - sensory nerve action potential. Reference values are the normative ones of the Neurophysiological Laboratory.

duction slowing and prolonged distal motor latency (DML), associated with focal nerve conduction slowing in common entrapment sites. All patients had increased DML of the median nerve, and the most common sites of focal nerve slowing (besides median nerve at the wrist) were the elbow (66.7\%) and the fibular head (26.7\%).

Two patients had distinct neurophysiological findings. The youngest patient, with a CMT-like atypical presentation, had a diffuse sensory-motor neuropathy with secondary axonal damage. The other patient had prolonged distal latencies of the sensory and motor responses of the median nerve, and absent/low amplitude SNAPs of the ulnar nerve, associated with a bilateral slowing of motor nerve conduction velocity and a partial motor-conduction block in the elbow segment, with normal motor and sensory study in the lower limbs.

\subsection{Genetic study}

Fifteen patients (88.2\%) carried the I7p I 2.2 deletion in PMP22 gene, the most common genetic abnormality related to HNPP. Two other patients from the same family (mother and son), were carriers of a point mutation in the PMP22 gene, and their clinical, neurophysiological and genetic findings were already described in a previous paper. ${ }^{9}$

\section{Discussion}

In our sample, male:female ratio (of approximately I) and age of first symptoms were in line with other patient series. ${ }^{1-3}$ In our cohort, HNPP is a disease that usually starts between the $2^{\text {nd }}$ and $3^{\text {rd }}$ decades of life, and there is a trend for the disease to begin in a younger age in typical HNPP presentations. Most of our patients did not have family history of the disease, but, as previously described, due to the insidious onset and sometimes mild and recurrent symptoms with full recovery, disease recognition is difficult only on clinical grounds.'

Regarding clinical presentation, it was noticed that atypical presentations were more frequently than usually reported. The presentation of $|4 p| \mid .2$ deletion as a progressive polyneuropathy has been identified since $1995^{13}$ and, in our cohort, progressive sensory-motor or sensory neuropathies were present in 
five patients with the aforementioned genetic change.

The patients with typical presentation exhibited clinical signs of a more generalized peripheral nervous system involvement, and two patients progressed to a chronic neuropathy. Recurrent positional shortterm sensory symptoms, often considered an atypica presentation for the disease, did not appear isolated in our patients, but instead constituted a common complaint, as reported in another small study with 12 patients. ${ }^{14}$ We highlight the importance to obtain a history of recurrent sensory complaints (numbness or tingling) related to pressure on upper or lower limbs.

In the patient with the GBS-like presentation, it was difficult to exclude an inflammatory super-imposed process at the beginning, as CSF results were not available. It was previously reported that CMT and HNPP patients may be susceptible to inflammatory peripheral nervous system acute disorders, ' but the patient continued to have GBS-like relapses, so the inflammatory hypothesis is less feasible.

In our cohort there are no asymptomatic patients, as reported in other patient series, and clinically observed sensory or motor signs in patients with both typical and atypical presentation do not have a major repercussion in ambulation, which makes HNPP a fairly benign condition. There is only one severe case, with impaired ambulation, as already previously described in the literature. ${ }^{15,16}$

NCS are also in line with previously reported findings - generalized changes in motor and sensory nerve conduction studies were the rule, being described as an asymmetric sensorimotor neuropathy with focal slowing on NCS; the most commonly affected nerves were, in upper limbs, the motor median and ulnar, and, in lower limbs, the peroneal, reflecting common sites of entrapment. Sural nerve sensory responses were abnormal in the majority of patients.

Clinical and genetic correlation has been difficult in HNPP. We believe that the girl with the atypical presentation of a severe neuropathy, with neurophysiological study showing a secondary axonal degeneration, might carry a yet unidentified point mutation or a genetic variant in the other PMP22 allele contributing to her phenotype. The most severe forms of HNPP were described in patients carrying compound heterozygous deletions, ${ }^{14}$ although in this patient next generation sequencing for hereditary neuropa- thies was negative. In the familial cases, genetic testing allowed recognition and diagnosis of other family members in two families, with previous generation patients having an undiagnosed neuropathy. It is noteworthy the intra-familial phenotypical heterogeneity, as previously reported. ${ }^{1,3-5}$

To summarize, current literature emphasizes the presence of atypical forms of HNPP, as observed in our group of patients. The related absence of clinicalelectrophysiological correlation highlights the importance of nerve conduction studies and genetic study for the definite diagnosis of the disease.

\section{Responsabilidades Éticas}

Conflitos de Interesse: Os autores declaram a inexistência de conflitos de interesse na realização do presente trabalho.

Fontes de Financiamento: Não existiram fontes externas de financiamento para a realização deste artigo.

Confidencialidade dos Dados: Os autores declaram ter seguido os protocolos da sua instituição acerca da publicação dos dados de doentes.

Proteção de Pessoas e Animais: Os autores declaram que os procedimentos seguidos estavam de acordo com os regulamentos estabelecidos pelos responsáveis da Comissão de Investigação Clínica e Ética e de acordo com a Declaração de Helsínquia da Associação Médica Mundial.

Proveniência e Revisão por Pares: Não comissionado; revisão externa por pares.

\section{Ethical Disclosures}

Conflicts of interest: The authors have no conflicts of interest to declare.

Financing Support: This work has not received any contribution, grant or scholarship

Confidentiality of Data: The authors declare that they have followed the protocols of their work center on the publication of data from patients.

Protection of Human and Animal Subjects: The authors declare that the procedures followed were in accordance with the regulations of the relevant clinical research ethics committee and with those of the Code of Ethics of the World Medical Association (Declaration of Helsinki).

Provenance and Peer Review: Not commissioned; externally peer reviewed.

\section{References / Referências}

1. Luigetti $M$, Grande $A D$, Conte $A$, Monaco $M L$, Bisogni $G$, Romano $A$, et al. Clinical, neurophysiological and pathological findings of HNPP patients with 17p12 deletion: A single-center experience. J Neurol Sci. 2014; 341:46-50. doi: 10.1016/j.jns.2014.03.046.

2. Mouton P, Tardieu S, Gouider R, Birouk N, Maisonobe T, Dubourg $\mathrm{O}$, et al. Spectrum of clinical and electrophysiologic features in HNPP patients with the 17p11.2 deletion. Neurology. 1999; 52:1440-6.

3. Oliveira A, Pereira R, Onofre P, Marques V, Andrade G, Barreira $A$, et al. Clinical and neurophysiological features of the hereditary neuropathy with liability to pressure palsy due to the 17p11.2 deletion. Arq Neuropsiquiatr. 2016;74:99-105. doi: 10.1590/0004-282X20160010.

4. Andreadou E, Yapijakis C, Parakevas GP, Stravropoulos P, Karadimas C, Zis VP, et al. Hereditary neuropathy with liabil- 
ity to pressure palsies: the same molecular defect can result in diverse clinical presentation. J Neurol. 1996; 243:225-30.

5. Lorenzoni PJ, Suemi C, Kay K, Cavalet C, Ardent, R, Werneck LC, Scola RS. Hereditary neuropathy with liability to pressure palsies: a single-center experience in southern Brazil. Neurol Int. 2016; 8:6677. doi: 10.4081/ni.2016.6677.

6. Takahasi S, Chum M, Kimpinski K. Electrodiagnostic characterization of hereditary neuropathy with liability to pressure palsies. J Clin Neuromuscul Dis. 2017;18:119-24. doi: 10.1097/CND.0000000000000152.

7. Ginanneschi F, Filippou G, Giannini F, Carluccio M, Adinolfu A, Frediani B, et al. Sonographic and electrodiagnostic features of hereditary neuropathy with liability to pressure palsies. J Peripher Nerv Syst. 2012;17:391-8. doi: 10.1111/j.1529-8027.2012.00437.x.

8. Dubourgh O, Mouton P, Brice A, LeGuern E, Bouche P. Guidelines for the diagnosis of hereditary neuropathy with liability to pressure palsies. Neuromuscul Disord. 2000; 10:206-8. doi: 10.1016/s0960-8966(99)00103-0.

9. Negrão L, Matos A, Geraldo A, Tavares P, Costa H. A novel peripheral myelin protein 22 point mutation with liability to peripheral nerve compression. Sinapse. 2010; 10.1:13-7.

10. Lenssen PP, Gabreels-Festen AA, Valentijn LJ, Jongen PJ, van Beersum SE, van Engelen BG, et al. Hereditary neuropathy with liability to pressure palsies. Phenotypic differences between patients with the common deletion and a PMP22 frame shift mutation. Brain. 1998;121:1451-8.

11. Foley C, Schofield I, Eglon G, Bailey G, Chinnery PF, Horvath R. Charcot-Marie-Tooth disease in Northern England. J Neurol Neurosurg Psychiatry. 2012; 283:572-3.

12. Goudier R, LeGuern E, Gugenheim M, Tardieu S, Maisonobe T, Léger JM, et al. Clinical, electrophysiologic, and molecular correlations in 13 families with hereditary neuropathy with liability to pressure palsies and a chromosome 17p11.2 deletion. Neurology. 1995; 45:2018-23.

13. Mancardi GL, Mandich P, Nassani S, Schenone A, James R. Defferrari $R$, et al. Progressive sensory-motor polyneuropathy with tomaculous changes is associated to $17 \mathrm{p} 11.2$ deletion. J Neurol Sci. 1995; 131: 30-4.

14. Phan L, Beydoun S. Diagnostic challenge of 12 cases of Hereditary Neuropathy with Liability to Pressure Palsy (HNPP). Neurology. 2018; 90: S15.

15. Asahina M, Kuwabara S, Hattori T, Asahina M, Katayama K. Respiratory insufficiency in a patient with hereditary neuropathy with liability to pressure palsy. J Neurol Neurosurg Psychiatry. 2000;68:110-1.

16. Al-Thihli K, Rudkin T, Carson N, Poulin C, Melançon S, Der Kaloustian VM. Compound heterozygous deletions of PMP22 causing severe Charcot-Marie-Tooth disease of the Dejerine-Sottas disease phenotype. Am J Med Genet A. 2008;146A:2412-6. doi: 10.1002/ajmg.a.32456. 